\title{
Department Self-Esteem and Attitudes towards Student Evaluations of Teachers
}

\author{
Bhaugeerutty Vinod Sharma \\ Hospital Road Centre De Flacq, Mauritius \\ E-mail: vsharma471@yahoo.co.uk
}

Received: May 17, 2017 Accepted: June 1, 2017 Published: June 5, 2017

doi: 10.5296/hrr.vli1.11351 URL: https://doi.org/10.5296/hrr.v1i1.11351

\begin{abstract}
Evaluation is an important part of education process at school. It plays a significant role in the development of school culture. This document deals with the terms connected with the evaluation process in teaching. It studied department self-esteem and attitudes towards student's evaluations of teaching in Mauritian secondary schools. The aim was to examine their opinions and attitudes to evaluation. Furthermore, the researcher tried to identify variables which could be linked to positive or negative attitudes towards evaluation. After several years of teaching experiences the researcher has tried to connect educators' attitudes towards evaluation in their classrooms, whereas other examined factors showed no significant differences in educators' attitudes.
\end{abstract}

Keywords: PRB (Pay Research Bureau), MGI (Mahatma Gandhi Institute), MGSS (Mahatma Gandhi Secondary School), ICT (Infomation Communication Technology)

\section{Introduction}

Education plays a vital part in our life today and it is a subject that has been frequently explored by researchers all over the world. The term evaluation has been derived from the French word "evaluation" exploring the issues like values, grading and assessing. According to the PRB Report 2008, the Mauritian government has put emphasis on educator's evaluation process with the aim to fulfil certain goals and assess validity or evaluate the realization.

Logan Wilson, former president of the University of Texas pointed that "indeed, it is no exaggeration to say that the most critical problem confronted by education sector is the proper evaluation of the departments and giving due recognition through impartial assignment of status". Reasoner (1992) stated that "Systematic, comprehensive, and valid evaluation of teaching has been an educational problem for many years. It continues to evade 
educators, although most head of schools and governments desire it as a meaningful way to determine rewards and sanctions for departments, and most serious educators seek it as a way of improving their performance and more closely relating what they do to what students learn.

It would appear that the problem of department evaluation has not been solved since Wilson's statement of more than 30 years ago. Dressel (2002) has further stated that department evaluation continues to be "sporadic in nature, limited in perspective and largely ineffective". As Wilson (1998) predicted, all of the schools would consider student ratings of instruction as a measure of "teaching quality" for their department.

\section{Statement of the Problem}

Although it is widely known and accepted that most department members resist the student evaluation process, few if any studies have been conducted that such investigate the reasons for this resistance, or harm that such resistance can cause.

Many department members believe the classroom is sanctified territory and that to make the results of student ratings available to a tenure committee or to the student body at large constitutes a violation of academic freedom with eventual loss of autonomy (Wachtel, 1998). As Dressel (2002) aptly points out, "Those who evaluate may ultimately direct and control." Other department members question the reliability of the rating device itself or the student's capability to rate teaching performance with any degree of validity. In addition, recognition of some department members as good educators inevitably carries the connotation that others are less good which may culminate in a threat to the department member's self-esteem.

\section{Background of the Study}

The Ministry of Education of Mauritius in collaboration with the Mauritius Institute of Education recently emphasized that secondary and primary schools need to reassess their commitment to instruction (Gokhool, 2008) and place greater importance on teaching (Dookhun, 2015). Most people, whether educators or students, would prefer not to be evaluated. Since evaluation of teaching performance by students can be threatening and ill-defined, and can sometimes result in unfair judgments, department's resistance is understandable.

Department resistance toward student evaluation of teaching is influenced, in part, by the many variables inherent in the situation: level and type of students taught, attractiveness of disciplines to students, curriculum difficulty, and difference between required and elective subjects - all factors over which department members exercise little control. In addition, much of department resistance to students' evaluation seems to be motivated by an ingrained and pervasive distrust of the student's ability to evaluate objectively.

Modern student evaluations of teaching practices were originally designed as a tool to be used formatively in support of department development and self-improvement (Simpson \& Siguaw, 2000; Stapleton \& Murkison, 2001; Trout, 1997; Zelby, 1974). Now they have a summative purpose as well: viewed as a convenient and ostensibly objective measure of teaching efficacy, they are employed in administrative decisions on salary and promotion (Stapelton \& Murkison, 2001; Trout, 1997). It is viewed as an incompetent judge, biased, immature, and arbitrary. Further, it is charged with confusing good teaching with 
showmanship and construing evaluations as an open invitation for retribution to get back at the department member for a grade or an unexpected grade. Finally, mechanical problems involved in the evaluation process have traditionally been a major concern for department.

Declining enrolments, scarce educational funding and continued societal pressure for teaching accountability have made most departmental members acutely aware of their tenuous positions, and the need for evaluation programmes that document educator contributions to the teaching-learning process. For too long, secondary education has been unaware of what is taking place in the classroom. At least as much as the student, educators need to learn which of their teaching practices is appropriate and effective and which are not, so that they can improve their performance. If the reasons for departmental member's resistance to student evaluation of teaching are analyzed and mitigated, then it may be possible to discern through student ratings what contribution the educator makes to what the student learns; and thus improve the whole educational process.

\section{Purpose of the Study}

The purpose of this study will be to assess the relationship between department self-esteem and attitudes toward student evaluation

\section{Significance of the Study}

Although in recent years the area of department evaluation has received much research attention, many research problems and questions remain unanswered. One such problem is related to the need for data about the individuals who have been evaluated, example, the school department members themselves. Most, if not all, of the research regarding the status of department evaluation has been gathered from school administrators such as rectors and deputy rectors.

Current research demonstrates that school administrators are highly satisfied with present department evaluation systems. What we do not know is the degree to which department are satisfied with these processes. To date, few studies have been conducted that seek to answer this question. This study will, therefore, attempt to analyze department attitudes relative to systematic student ratings of teaching performance.

By examining the relationship between department attitudes toward student ratings of teaching performance and level of department self-esteem, the study will suggest direct answers to the question of department resistance to student evaluations and may lead to revisions of existing department evaluation systems. Indirectly, the study may also influence department development programmes.

\section{Hypothesis}

The higher the level of a department member's self-esteem the less resistant he/she will be toward student ratings of teaching performance.

\section{Definition of terms}

Department evaluation: Both the process and the result of ascertaining the value of a department member's contribution to the teaching-learning process in his/her institution.

Teaching performance: A complex set of attitudes, knowledge, skills, motivations, and values a Educator brings to the classroom, and the behaviour that results from them 
Systematic student ratings: Written assessments (judgments) of a Educator's performance carried out at recurring intervals

Self-esteem: The need for a stable firmly based high evaluation of oneself, and for the respect of others.

Loss of autonomy: The Educator's perception of losing possession of self-directing freedom in the classroom.

Resistance: The inherent capacity of a human being to withhold assent to undesirable events

\subsection{Assumption}

- Department members are an important educational source and their teaching performance must be systematically refined.

- Department members are committed to teaching and are continually striving for self-improvement.

- An attitude rating scale is a valid and reliable methodology for collecting data for the study.

- Systematic student ratings can provide department with information for improving teaching performance.

\section{Literature Review Plan}

Many Studies have already been carried out in this area of research in one way or the other. Among them includes the study which suggests that students' perceptions of Educator behavior has significant impact on their self-esteem (Kususanto, Ismail, \& Jamil 2010). This finding also supports the theories brought forward by previous researches saying that, it is not the evaluation of oneself alone that generated self-esteem; how a person thinks others would value him or her would also generate his/her self-esteem. (Bandura, 1997, Burns, 1975, 1982; Coppersmith, 1967, Horrock's \& Jackson, 1972, Myers, 2008, Stryker, 2002). Other studies by Good (1981) and Slavin (1987) noted in addition that Educators assigned in Low achiever category seemed to have more of lower expectations on the students than they were reported to have higher expectations in Lower achiever category.

From a preliminary review of the literature it became apparent this study focuses on a problem that has not been investigated before. Therefore, a rather unusual approach to the literature review is being adopted by the researcher. Indeed, a survey of the literature indicates that hundreds of studies on student evaluations of department teaching performance have been conducted, but to date, no study has investigated department members' attitudes toward this procedure. Consequently, theories and concepts which might account for attitudes are included in the literature review.

As a starting point a conceptual framework will establish a common meaning for essential concepts and also provide a similar frame of reference for the reader. To illustrate how department attitudes toward student evaluations of teaching performance are established, the framework portrays relationships among four concepts, beliefs, attitudes, behavioural intentions, and behaviour. Most importantly, the framework provides a rational explanation as to how and why the various elements concerned with the study, department attitudes 
toward student evaluations; department self-esteem and autonomy are related.

In the next section, a theoretical orientation is analyzed in terms of the conceptual framework. The subsequent sections deal with the literature concerning the categories of self-esteem, and department evaluation. Attitude ratting scales constitute the final segment.

\subsection{Belief}

Beliefs are the fundamental building blocks in the conceptual framework used for this study. On the basis of information received from outside sources, from direct observation, or by way of various inference processes, an individual learns or forms a number of beliefs concerning an object. In other words, one associates the object with various attributes. In this manner one forms beliefs about oneself, about other people, about institutions, behaviour events, etc. The totality of an individual's beliefs serves as the informational base that ultimately determines one's attitudes, intentions and behaviours.

\subsection{Attitudes}

An attitude can be described as a learned predisposition to respond (behave) in a consistently favourable or unfavourable manner with respect to a given object. Subsequently, attitude is determined by an individual's belief that the object has certain attributes and by one's evaluation of those attributes. Most individuals hold both positive and negative beliefs about an object, and attitude is viewed as corresponding to the total evaluation associated with their beliefs.

In terms of the relationship between beliefs and attitudes, the conceptual framework thus suggests that an individual's attitude toward some object is related to a set of his beliefs about the object, but not necessarily to any specific belief. Similarly, an individual's attitude toward performing a given behaviour is related to one's beliefs that performing the behaviour will lead to certain consequences and also to one's evaluation of those consequences. For clarification, attitude refers to a person's favourable or unfavourable evaluation of an object, while beliefs represent the information one has about the object.

\subsection{Behavioural Intentions}

Behavioural intentions refer to an individual's intention to perform various behaviours. Since most social behaviour is viewed as volitional (example, act of choice), an individual should perform those behaviours he/she intends to perform.

\subsection{Behaviour}

In this framework, behaviour is considered as overt and refers to all observable acts of the individual. This includes both questionnaire and verbal responses. Although such responses may be treated as records of behaviour, they are instead utilized in this study to infer beliefs, attitudes and/or intentions.

One obvious source of information about beliefs is direct observation. Direct experiences with a given object result in the formation of descriptive beliefs about the object, which in this study, are expressed in response to a questionnaire. There is no necessary connection between such responses and a department member's real-life action, so the results of this study are both focused on attitudes department are willing to express and limited to them. These inherent limitations must be added to limits imposed by sample bias, instrument unreliability, and non-response. 


\section{Research Methodology}

The purpose of this study used the methodology of correlational research where several characteristics of the school department members have been correlated to discover the extent to which they were related. Department self-esteem and department attitudes towards student ratings of teaching performance have been assessed to determine the way they varied together with other intervening variables controlled.

The population for the study will include all departmental members from State, Private and MGI/MGSS schools. From this group, a study sample of 20 subjects will be randomly selected across undergraduate disciplines.

Department members will be identified as assigned to a different discipline of the secondary school curriculum. From each group a proportionate number of subjects will be randomly selected so that each teaching discipline will have equal representation in the study.

In this study, level of self-esteem is viewed as the predictor or independent variable (low-mid-high level of self-esteem). This research study is viewing self-esteem status as a cause; results are dependent upon differences in the independent variable, which is viewed as a random variable.

Department attitudes toward student ratings are viewed as the dependent variable because it should vary in some relationship to the independent variable (self-esteem).

Loss of autonomy is viewed as an intervening variable because its effect will be to influence the relationship between the independent variable (level of self-esteem), and the dependent variable (attitudes toward student ratings). It would "intervene" if a positive relationship between level of self-esteem and department attitudes toward student ratings were to exist only for those department members with average loss of autonomy. For those with high loss and for those with low loss of autonomy, there would be no relationship between the independent and the dependent variables.

Other intervening or test variables to be considered in this study will be the department member's sex, age, academic rank, tenure status, and department. These variables will also help determine the way the independent variable will serve as aids to understanding the primary relationship.

\section{Data Collection and Data Analysis}

A questionnaire format will be utilized to gather data for the study. Scores on a measure of self-esteem will be correlated with scores on a researcher constructed questionnaire of attitudes toward student evaluations, and to responses to demographic items.

Bivariate Correlation Analyses will be used to examine the data and test the hypothesis of this study. Bivariate correlation provides a single number which summarizes the relationship between two variables (self-esteem and department attitudes toward student ratings), and produces a single summary statistic describing the strength of the association. This statistic is the correlation coefficient. These correlation coefficients indicate the degree to which variation (or change) in one variable is related to variation in another.

Correlation analysis refers to the relationship between two variables or the degree to which 
two variables are related and follow the same linear path (Kerlinger \& Lee, 2000). The purposes are to learn about the relationship among variables and to make predictions based on the relationships. Post hoc analyses were conducted where appropriate.

Further hypothesis testing and analysis of relationships will be performed by the partial correlation procedure. This technique provides a single measure of association which describes the linear relationship between two variables while controlling for the effects of one or more additional variables. Partial correlation will enable the researcher to remove the effect of the control variable from the relationship without manipulating the raw data.

\section{Consequences}

As a consequence of a study that measures department attitudes towards student evaluations of teaching performance, useful information will be provided for all those concerned with higher education, example, department, administrators, students, institutions of higher learning, and society at large.

Certainly, the continuing dissatisfaction of the general public with higher education can be to some extent mitigated by a well-advertised programme of evaluation, which can simultaneously be interpreted as an effort towards department accountability.

From an institutional point of view, a study of this nature will provide guidelines for those considering the implementation or revision of their department evaluation programs. Indirectly, the study will provide guidance for department development programs that may be directed towards increasing department self-esteem, or altering department attitudes towards student ratings of teaching performance.

In addition, this study, by focusing on the department as subjects will undoubtedly open the door for future studies that will utilize department as informational sources relative to the evaluation process. The use of this information will lead to greater department acceptance of evaluation as their viewpoints are considered in the designing and/or revision of evaluation programs. Concomitantly, department will utilize the evaluation system with consistency if it is deemed a valid and non-threatening process. Subsequently, by using department input into the evaluation system, future evaluation programmes may be implemented so as to eliminate department resistance to the process.

Also, the use of the evaluation system may ultimately single out those teaching skills and behaviours that are identified with effective teaching. Further, if the evaluation process is utilized by the entire department, then it will be another source of information for administrators to use in evaluating department relative to promotion, retention and tenure decisions.

As far as students are concerned, a closer relationship will no doubt develop between department and students as they actively participate in decisions relative to classroom teaching, and serve in an evaluator role providing the department members with teaching performance feedback. Eventually, teaching performance will improve over a period of time.

Indeed, a goal of higher education is the development of department evaluation systems that demonstrate a reputation for teaching excellence. However, since Wilson's statement some 30 years ago, higher education has made imperceptible progress toward the designing and implementation of equitable department evaluation programmes. The intent of this study is to 
hasten the process toward this end.

\section{Ethical Consideration}

All data will be collected with complete confidentiality and anonymity of participants fully upheld and guaranteed by the researcher. Interview and focus group transcriptions will be closely scrutinized and edited to ensure that participant responses do not reveal or suggest the identity of the department or individuals involved in the study. Data collection will proceed in a timely, efficient and professional manner, demonstrating sincere respect for the commitment and trust that participants will place in the researcher and the study.

\section{Structure of the Study}

The study consists of five chapters,

\section{- Chapter 1 Introduction and overview of the study}

Chapter one is an introduction and highlights the motivation of the study. This chapter will focus on the purposes and rationale of the study, research objectives, problem statement and delimitations.

\section{- Chapter 2 Literature review}

Chapter two is comprised of a review of literature on department attitudes towards student evaluations of teaching performance.

\section{- Chapter 3 Research Methodology}

Chapter three describes research methodology that will be used for the study. This chapter also includes the research design, data collection, data analysis, validity and reliability.

\section{- Chapter 4 Presentation of results}

Chapter four covers the presentation and research findings, analysis of the data and interpretation of the results in accordance with theory discussed in the literature review.

\section{- Chapter 5 Conclusions and Recommendations}

Chapter five contains the conclusions and recommendations of the study

\section{References}

Bandura, A. (1997). Self-Efficacy: The exercise of control. New York, NY: Freeman.

Burns, R. B. (1982). Self-Concept Development and Education. Dorchester: Holt. Rinehart and Winston

Cameron, K., \& Ettington, D. (1988). The conceptual foundations of organsiational culture. In J C. Smart (Ed.), Higher education: Handbook of theory and research (vol.4). New York: Agathon Press.

Coppersmith, S. (1967). The Antecedents of Self Esteem. San Francisco: Freeman.

Des Jarlais, Christine D. (1996). Determinants of department morale in an American public research university: Gender differences within and between academic departments. Dissertation Abstracts International, 56(10-A), 3847.

Dressel, H. (2002). Good news for a change: How everyday people are helping the planet. Toronto, ON: Stoddart Publishing Company

Ewell, P. T. (1989). Institutional characteristics and department/administrator perceptions of 
outcomes: an exploratory analysis. Research in Higher Education, 30, 113-136. https://doi.org/10.1007/BF00992715

Good, T. L. (1981) Educator's Expectancy and students' Perception: a decade of research. Educational Leadership, 38,415-422.

Halford, A. (1984). Department morale-Enhancing it in spite of diminishing resources and challenges. Paper presented to the International Conference for Community College Chairs, Deans, and Other Instructional Leaders, Phoenix, AZ.

Horrocks, J. E., \& Jackson, D. W. (1972). Self and Role: A Theory of Self-Process and Role Behavior. Bosten: Houghton Mifflin Company.

Johnsrud, L. K. (1996). Maintaining Morale: A guide to assessing the morale of midlevel administrators and department. The College and University Personnel Association: Washington, DC.

Kerlinger, F. N., \& Lee, H. B. (2000). Foundations of Behavioral Research, 4th ed. Philadelphia: Harcourt College Publishers.

Kolb, D. (1998). Learning styles and disciplinary differences. In A. Chickering (Ed.), The modern American college (pp. 232-255). San Francisco: Jossey-Bass.

Kususanto, P., Ismail, H. N., \& Jamil, H. (2010). Students' Self Esteem and their Perception of Educator Behavior: A study of Between Class Ability Grouping. Electronic Journal of Research in Educational Psychology, 8(2), 707-724.

Maslow, A. (1954). Motivation and Personality. New York: Harper \& Row. https://doi.org/10.1111/j.1467-6494.1954.tb01136.x

Myers. D. G. (2008). Social Psychology. Holland, MI: McGraw Hill.

Perry, R. P., \& Smart, J. C. (Eds.). (1997). Effective Teaching in Higher Education. Agathon Press: New York.

Read, W. J., Rama, D. V., \& Raghunandan, K. (2001). The relationship between student evaluations of teaching and department evaluations. Journal of Education for Business, 76(4), 189-193. https://doi.org/10.1080/08832320109601309

Reasoner, R. W. (1992). Building Self-Esteem in the Elementary Schools, Educator's Manual. Calif: Consulting PsycholOgists Press, Inc.

Rendall, N. D., Wesson, C., Anderson, L., \& Bould, E. (2009). Students' Goal Achievement: Exploring Individual and Situational Factors. Electronic Journal of Research in Educational Psychology, 7(3), 1031-1052.

Rogers, C. R. (1980). A way of being. Boston: Houghton Mifflin.

Salvin, R. E. (1987). Ability Grouping and Student Achievement in Elementary Schools. Review of Educational Research, 57293,-366

Simpson, P. M., \& Siguaw, J. A. (2000). Student evaluations of teaching: An exploratory study of the department response. Journal of Marketing Education, 22(3), 199-214. https://doi.org/10.1177/0273475300223004

Smart, J. (1985). Holland environments as reinforcement systems. Research in Higher Education, 23, 279-292. https://doi.org/10.1007/BF00973791

Stapleton, R. J., \& Murkison, G. (2001). Optimizing the fairness of student evaluations: A 
study of correlations between instructor excellence, study production, learning production, and expected grades. Journal of Management Education, 25(3), 269-291. https://doi.org/10.1177/105256290102500302

Stryker, S. (2002) Symbolic Interactionism: A Social Structural Version. Caldwell, NJ: Blackburn Press.

Wachtel, H. K. (1998). Student evaluation of college effectiveness: a brief review. Assessment and Evaluation in Higher Education, 23(2), 191-211. https://doi.org/10.1080/0260293980230207

Wilson, R. (1998). New research casts doubt of student evaluation of professors. The Chronicle of Higher Education, 44(19), 12-14.

\section{Appendix 1}

\section{Section A: Personal Data}

1. Sex: Male $\square$ Female

2. Age

Below 25 years old

25-35 years old

36-45 years old

46-55 years old

Over 55 years old

3. Department

English

French

Maths

Oriental Languages

Science

ICT

Music

Physical Education

Food and Fashion

Design and Communication

Business and Economics

Accounting

Others, please specify 
4. Years at present institution

Less than 1 year

1 to 5 Year

5 to less than 10 years

More than 10 years

\section{Section B: Self esteem}

1. Do you like the department?

$\mathrm{Y} \square \quad$ NO $\square$

If no please specify why?

Please use the following scale as you answer each question:

$\mathbf{1}=$ rarely $\mathbf{2}=$ once in a while $\mathbf{3}=$ sometimes $\mathbf{4}=$ most of the time $\mathbf{5}=$ almost always

\begin{tabular}{|l|l|l|l|l|l|l|}
\hline \multicolumn{2}{|c|}{ Descriptive Analysis of Students' General Self-Esteem } & 1 & 2 & 3 & 4 & 5 \\
\hline 1 & I get along with students easily. & & & & & \\
\hline 2 & In general, I like being the way I am & & & & & \\
\hline 3 & Other students like me to be their friend & & & & \\
\hline 4 & I like myself in general. & & & & \\
\hline 5 & I have many friends. & & & & \\
\hline 6 & Other students feel I am a good person & & & & \\
\hline 7 & I am popular among students of my age. & & & & \\
\hline 8 & A lot of things about me are good & & & \\
\hline
\end{tabular}

9. What is self-esteem?

10. List some factors affecting self esteem 
Section C: Educator evaluation by students

\begin{tabular}{|c|c|c|c|c|c|c|}
\hline \multicolumn{2}{|r|}{$\begin{array}{l}\text { EXPLICIT CURRICULUM: } \\
\text { How well does the Educator teach the core subject? }\end{array}$} & 1 & 2 & 3 & 4 & 5 \\
\hline 1 & Educator is prepared for class. & & & & & \\
\hline 2 & Educator knows his/her subject & & & & & \\
\hline 3 & Educator is organized and neat. & & & & & \\
\hline 4 & $\begin{array}{l}\text { Educator plans class time and assignments that help students to } \\
\text { problem solve and think critically. Educator provides activities } \\
\text { that make subject matter meaningful. }\end{array}$ & & & & & \\
\hline 5 & $\begin{array}{l}\text { Educator is flexible in accommodating for individual student } \\
\text { needs. }\end{array}$ & & & & & \\
\hline 6 & $\begin{array}{l}\text { Educator is clear in giving directions and on explaining what is } \\
\text { expected on assignments and tests }\end{array}$ & & & & & \\
\hline 7 & $\begin{array}{l}\text { Educator allows you to be active in the classroom learning } \\
\text { environment }\end{array}$ & & & & & \\
\hline 8 & Educator manages the time well. & & & & & \\
\hline 9 & Educator returns homework in a timely manner. & & & & & \\
\hline 10 & $\begin{array}{l}\text { Educator has clear classroom procedures so students don't } \\
\text { waste time. }\end{array}$ & & & & & \\
\hline 11 & Educator grades fairly & & & & & \\
\hline 12 & I have learned a lot from this Educator about this subject. & & & & & \\
\hline 13 & $\begin{array}{l}\text { Educator gives me good feedback on homework and projects so } \\
\text { that I can improve. }\end{array}$ & & & & & \\
\hline 14 & Educator is creative in developing activities and lessons. & & & & & \\
\hline 15 & $\begin{array}{l}\text { Educator encourages students to speak up and be active in the } \\
\text { class. }\end{array}$ & & & & & \\
\hline
\end{tabular}

\begin{tabular}{|c|c|c|c|c|c|c|}
\hline \multicolumn{2}{|r|}{$\begin{array}{l}\text { IMPLICIT CURRICULUM: } \\
\text { How well does the Educator model the core values through how } \\
\text { he/she behaves with students and with other staff persons? }\end{array}$} & 1 & 2 & 3 & 4 & 5 \\
\hline 16 & $\begin{array}{l}\text { Educator follows through on what he/she says. } \\
\text { You can count on the Educator's word }\end{array}$ & & & & & \\
\hline 17 & $\begin{array}{l}\text { Educator listens and understands students' point of view; he/she } \\
\text { may not agree, but students feel understood. }\end{array}$ & & & & & \\
\hline 18 & Educator respects the opinions and decisions of students. & & & & & \\
\hline
\end{tabular}




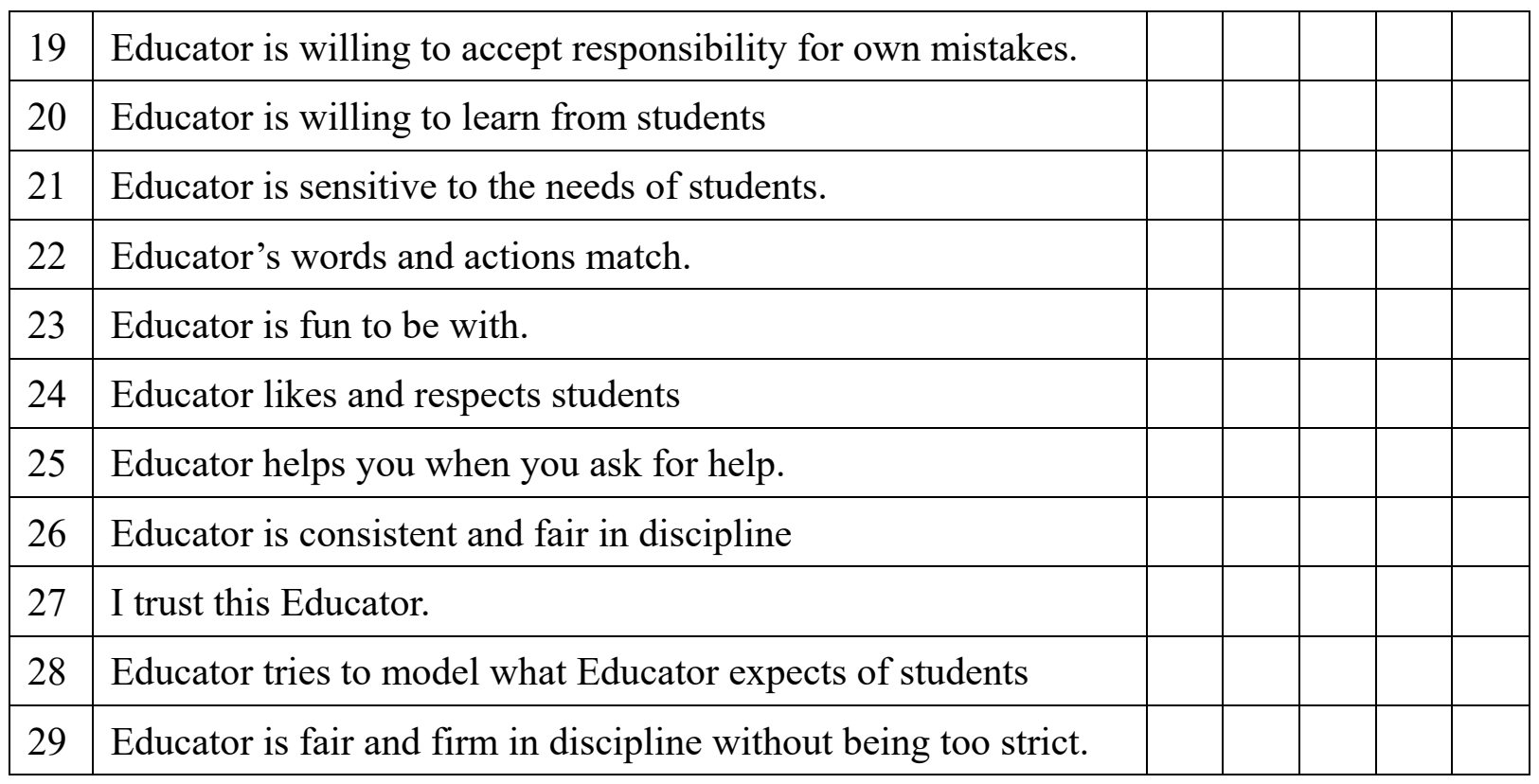

30. What is one thing that your Educator does well?

31. What is one thing that you can suggest to help this Educator improve?

33. Tell me about the lesson where you learned the most and why you think so.

$* * * * * * * * * * * * * * * * * * * * * * * * * * * * * * * * * * * * * * * * * * * * * * * * * * * * * * * * * * * * * *$

Thank you for your kind cooperation.

\section{Copyright Disclaimer}

Copyright for this article is retained by the author(s), with first publication rights granted to the journal.

This is an open-access article distributed under the terms and conditions of the Creative Commons Attribution license (http://creativecommons.org/licenses/by/3.0/). 